\title{
The Judgment of the European Court of Human Rights in the Case of Preda and Others v. Romania: Prospects of Further Practice in Cases Related to the Property Restitution in Romania
}

\begin{abstract}
PÉTER BÓNIS
Abstract. After the fall of the communist regime, the Romanian State adopted a series of laws to redress the violations of property rights caused by that regime. Romania has been condemned in numerous restitution cases decided by the European Court of Human Rights, because the implementation of property restitution legislation has proceeded exceedingly slowly. This paper aims to investigate the main causes of this delay taking into consideration the new legislative framework of Property Restitution and the new judgements of the European Court of Human Rights (ECHR) against Romania.
\end{abstract}

Keywords: restitution, Romania, European Convention of Human Rights, right to ownership, nationalization

\section{INTRODUCTION}

„While progress has taken place since the fall of Communism and subsequent breakup of the Soviet Union, there remains an urgent need to help the tens of thousands of elderly Holocaust victims and their heirs whose property claims remain unsatisfied," said World Jewish Restitution Organization President Ronald S. Lauder, who is also the president of the World Jewish Congress. "We are disappointed that Romania, which did enact restitution laws, has failed to address the bureaucratic delays that have stalled the restitution and compensation process," said Lauder. "I call on those countries that have been slow to move on this issue now. Time is running out. Survivors cannot accept that property stolen from them and those who perished is not being returned. The countries in question must do the right thing. Justice must be done, and seen to be done," he said. ${ }^{1}$

The press statement released on 28 November 2012 by President Ronald S. Lauder has well described a very unpleasant situation. Romania has passed a series of laws dealing with the restitution of confiscated communal and private real property, but their implementation has proceeded exceedingly slowly (Bazyler-Alford 2006: 304-310). This paper aims to investigate the main causes of this delay taking into consideration the new judgements of the European Court of Human Rights (ECHR) against Romania.

1 Press statement released on 28 November 2012, available at $<$ http://www.worldjewishcongress. org/po/news/

12715/jewish_groups_urge_poland_latvia_and_romania_to_deal_with_holocaust_era_property_ restitution?print $=$ true $>$.

Péter Bónis, PhD, adjunct professor, Károli G. University, 1042 Budapest, Viola u. 2-4, E-mail: Bonis@mailbox.hu.

(Received: 26.06.2014; revision received: 21.07.2014; accepted: 15.09.2014) 


\section{THE RESTITUTION ISSUE IN ROMANIA}

After the fall of the communist regime, the Romanian State adopted a series of laws to redress the violations of property rights caused by that regime. ${ }^{2}$ The scope of a first set of laws, adopted between 1991 and 1997, was subsequently expanded in 2000 and 2001. The Romanian restitution legislation covered restitution not only to original owners or their descendants, but also to a new class of owners who had never held a title to the land.

Initially, applications are examined by the local authorities, which decide on restitution in kind or the award of compensation. Restitution is required by law when possible. In practice, it is granted in a minority of cases. Only $30 \%$ of the requests filed under Law 10/2001 which have received an administrative solution (excluding claims rejected) resulted in some form of restitution.

Restitution of the original property is not possible in the case of buildings which have been demolished or apartments that are occupied by former tenants who purchased the property under Law 112/1995. In these cases, based on art. 1, al. 2-5 of Law 10/2001, local authorities are required to give other buildings owned by the state, unless they serve some critical purpose. Yet this solution was only practiced in $4 \%$ of the cases receiving a favorable administrative solution (Ferenţiu 2007: 149).

With the passage of Law 112/1995, tenants gained the right to buy their state-owned apartments from the government. However, many apartments sold by the government were the subject of litigation by former owners, and in many cases former owner's legal titles to the apartments had already been recognized by courts.

This gave rise to overlapping rights to the same properties. Law 10/2001 added to the ambiguity, allowing former owners to challenge tenants' titles if not obtained in good faith. Often guided more by individual judge's ideological leanings than by the specific circumstances of the cases, some courts favoured the rights of former owners, others favoured those of tenants, while different panels of the same courts often gave contradictory rulings ${ }^{3}$ on the same day.

Cash compensation was suspended in 2010, leaving the Property Fund as the only compensation vehicle. While the Property Fund as a compensation vehicle has almost been exhausted, the government has not announced any new sources of compensation.

On 12 October 2010 the European Court of Human Rights delivered a pilot judgment in the case of Maria Atanasiu and Others v. Romania, in which it held that the Romanian State was to take measures to ensure the effectiveness of the compensation and restitution mechanism and the effective protection of the rights set forth in Article $6 \S 1$ (right to a fair trial within a reasonable time) of the Convention and Article 1 of Protocol No. 1 (protection of property) to the Convention (Quesada 2013: 694-705).

On 16 May 2013 the Romanian Parliament passed Law no. 165/2013 on finalisation of the process of physical restitution or alternative compensation in respect of immovable property that wrongly passed into State ownership during the communist regime.

2 The acronyms cited in this paper: ADS=Agenţia Domeniilor Statului (State Land Agency), ANRP=Autoritatea Naţională pentru Restituirea Proprietăţilor (National Agency for Property Restitution), ECHR=European Court of Human Rights, HG=Hotărârea Guvernului României (Government decree), L=lege (Act, Law), O.U.G=Ordonanţa de urgenţă a Guvernului (Emergency Government Ordinance), $\mathrm{OG}=$ Ordonanţa Guvernului (Government ordinance).

3 In details, see Străin et autres c. Roumanie, no 57001/00, CEDH 2005-VII, Păduraru c. Roumanie, $\mathrm{n}^{\circ}$ 63252/00, CEDH 2005-VII 


\section{JUDGEMENT IN THE CASE OF PREDA VS. ROMANIA}

On 29 April 2014 the ECHR issued a judgement in the case of Preda and eight other applicants vs. Romania. The applications were lodged with the European Court of Human Rights between 3 December 2001 and 9 June 2004. These eight applications are the first to have been examined by the Court since the pilot-judgment procedure conducted in the case of Maria Atanasiu and Others. The cases are complex on account of the time that has elapsed since the victims were dispossessed of their property, and as a result of developments in the political and legal solutions proposed since the fall of the communist regime. ${ }^{4}$

Relying on Article 1 of Protocol No. 1 (protection of property) to the Convention, the applicants complained that the restitution and compensation laws were ineffective.

The Court had to determine whether the remedies provided by Law no. 165/2013 and its implementing regulations were effective in dealing with the applicants' situation.

The Court noted that Law no. 165/2013 had not repealed the previous restitution laws but had supplemented them and amended them in certain respects. The Law had introduced a new compensation procedure involving a "points" system that entitled claimants to take part in public auctions. Where the points were not used to purchase property at an auction, the law permitted an award of monetary compensation. The amount was calculated on the basis of the market value of the property in question and was payable in instalments. The Law set time-limits for each administrative step and provided for the possibility of judicial review, which gave the courts the opportunity to examine the lawfulness of decisions by the administrative authorities and, where necessary, to give rulings in their place conferring title or awarding compensation. Where there were multiple documents of title for the same plot of land, the Law provided for the invalidation of the most recent document(s) and the award of compensation. The Court noted, however, that the Law contained no provisions dealing with the question of court decisions that had validated competing documents of title to the same building. Furthermore, where restitution was impossible because of an act carried out after the time-limit for bringing a claim for compensation, no other procedural route was open to former owners who would otherwise be entitled to such an award.

Having regard to the margin of appreciation enjoyed by the Romanian State and the guarantees afforded by Law no. 165/2013, the Court considered that the Law in question provided, in principle, an accessible and effective framework of redress for alleged violations of the right to peaceful enjoyment of possessions. However, it found that the Law did not contain any provisions capable of affording redress in cases where there were multiple documents of title for the same building.

The Court observed that, on account of the time-limits laid down in the Law, the completion of the process and the final settlement of claims could take many years. This exceptional state of affairs was inherent in the factual and legal complexity surrounding the status of property which had been nationalised or confiscated more than 60 years previously and which had undergone many successive changes of owner and use. In view of the singular nature of this state of affairs, the Court considered that these time-limits could not call into question the effectiveness of the revised mechanism or be deemed contrary to the right under Article 6 of the Convention to have proceedings conducted within a reasonable time. Bearing in mind that, as Law no. 165/2013 had been enacted only recently, no judicial or administrative practice had yet emerged as regards its application, the Court could see no

${ }_{4}$ Preda et autres c. Roumanie, $\mathrm{n}^{\text {os }}$ 9584/02, 33514/02, 38052/02, 25821/03, 29652/03, 3736/03, 17750/03 et 28688/04, CEDH 123 (2014). 
reason to conclude at this stage that the new remedy was ineffective. It therefore found that - except in situations where there were multiple documents of title for the same building Law no. 165/2013 in principle offered litigants an opportunity to obtain redress for their grievances at national level; it was for them to avail themselves of that opportunity.

In application no. 3736/03 Mr and Mrs Rodan had stated that their title to a flat in Bucharest - which had been confirmed by a court decision - had not been declared void and that they had yet to be paid any compensation for the loss of that property. The Court observed that it had held in previous cases that a ruling by the domestic courts that the nationalisation of property had been illegal amounted to an acknowledgment of title to the property in question, with retrospective effect. Having regard to the domestic court's ruling that the State had illegally taken possession of the building in question and was thus required to return it to the applicants as the lawful owners, the Court held that their being deprived of their property and not being paid any compensation at all over a period of many years was at variance with Article 1 of Protocol No. 1 and concluded that there had been a violation of that Article in respect of Mr and Mrs Rodan's property.

The Court held that Romania was to secure to Mr and Mrs Rodan the enjoyment of their property as established in the domestic court's judgment and that, failing this, it was to pay them jointly 200,000 euros (EUR) in respect of pecuniary damage. The Court also awarded Mr and Mrs Rodan jointly EUR 5,000 in respect of non-pecuniary damage and EUR 3,000 in respect of costs and expenses.

The main deficiency of the judgement issued in the case of Preda vs. Romania is that the ECHR seems to ignore the Law no. 368/2013 amending Law no. 165/2013, the HG 401/2013, the HG 89/2014, the OUG 115/2013 and other detailed ANCPI regulations and the decisions of the Constitutional Court of Romania. ${ }^{5}$ In particular, the composition of the local land inventory boards was changed in a significant way, and the rules on inventory procedure were changed, as well. It is strange enough that the ECHR ignores this important amendment.

There are some other questions that the ECHR seems to be unwilling to take into consideration. The aim of our paper is precisely to analyse these ignored questions.

\section{THE MAIN PROBLEMS IN ROMANIAN ADMINISTRATIVE SYSTEM OF RESTITUTION}

The Romanian restitution system is ineffective mainly not because of the deficiencies of the legislative norms, but because so many laws have given rise to unsatisfactory practices by local and national authorities and courts. Claimants face excessive and unpredictably long delays in receiving decisions from local authorities and compensation from national authorities. Rulings by the High Court of Cassation and Justice meant to clarify the tangle of laws have made further modifications in practice, but rulings by lower courts remain inconsistent, and the non-execution of court decisions is pervasive.

However, the main problems of the Romanian restitution and compensation system are of administrative nature. The ECHR seems to forget that Romanian administrative law and entities are mostly ineffective, and simple administrative tasks, which can be done without

5 There are 93 pending cases before the Romanian Constitutional Court according to Berechet, M. (2013): Caracterul concret şi efectiv al dreptului de proprietate asupra imobilelor preluate abuziv în perioada regimului comunist în România conferit prin măsurile de restituire instituite de Legea nr. 165/2013, Revista Română de Jurisprudenţă 4(4): 189. 
problems in other Western European countries, are difficult to do in Romania. Most problems of the restitution system have nothing to do with the compensation issue of former owners, but it is simply a consequence of the ineffectiveness of the Romanian administrative law and system, especially the land registry system. It is very strange that the ECHR disregarded these issues, while stressing the structural nature of these issues.

\section{a) Too many commissions - little individual responsibility}

The characteristic of the Romanian restitution system is that almost every restitution decision is made by committees, commissions and boards. Law no. 165/2013 is not an exception, because it sets up new bodies, namely local land inventory boards. They will have to be set up within the 30 days that follow the entry into force of the new law (Art. 5, alin. 1). The law also provides for the Central Compensation Board, which currently functions in accordance with the compensation legislation in force, to be replaced by a National Immovable Property Compensation Board (the "National Board"), reporting to the Prime Minister (Art. 18 and 19). ${ }^{6}$

It was a general experience during years 2000-2014 that these commissions are rather an obstacle of the restitution process. It was very difficult to set up a commission within the statutory time limit. The commission members were also members of other commissions or they had important public and administrative functions, like the mayor (primar). They were often absent, and as the presence of an absolute majority of the members of the Commission was necessary to constitute a quorum, it was very difficult to hold regular periods of sessions. Therefore, long periods of inactivity were not rare.

These commissions made decisions by the majority vote of its members, therefore the members' responsibility was unclear. As the decisions were of collective nature, everyone declined the individual responsibility in case of accusation of illegality. Although corruption allegations were frequent, condemnations were rare.

The restitution board members are often politicians and this is another important obstacle to the correct functioning of these boards. The politicians should be excluded from these boards, because the decisions of restitution should not be of a political nature, but only an application of legal norms enacted by the Romanian Parliament.

In other former socialist countries, the restitution decisions were issued not by commissions full of politicians, but by individual officials. This structure of decision process based on commissions and boards full of politicians are ineffective, and it should be replaced by a decision process made by individual officials controlled by another official on the ground of clear legal norms.

\section{b) Lack of a second administrative level of controll and appeal}

Another characteristic feature of the Romanian administrative system is that every case is decided before only one level of administrative jurisdiction, except for the fiscal cases. In case of excessive long delays or unlawful decisions of the local land board or the mayor, the applicants were constrained to address a judge in court.

${ }^{6}$ Strain and Others against Romania and Maria Atanasiu and Others against Romania (and 266 similar cases) group. General measures for the execution of the judgments of the European Court. Memorandum prepared by the Department for the Execution of Judgments of the European Court of Human Rights, in close co-operation with the Registry of the European Court, H/Exec(2013)1, 10 April 2013, § 27. 
If we take into consideration the huge caseload of the courts, it would not be unreasonable, if an aggrieved party should pursue all administrative remedies before filing a lawsuit in civil court to resolve the disagreement. An administrative appeal (which is missing now) could be an appropriate administrative remedy. An obligatory administrative appeal should go to an administrative institution different from the initial decision maker (e.g. should go to the prefect to obtain restitution). By contrast, a petition for reconsideration which is addressed to the same administrative institution that made the initial decision (e.g. cf. fiscal disputes in Romania) should be avoided, because this would not be an independent forum, and there is no reason to require the local administrative authority who made the initial decision to have a second opportunity to make a decision, and no change in the agency's position is likely when the same administrative body addresses the same facts and law.

\section{c) Functioning of the local land inventory boards}

The new law sets up new bodies, namely local land inventory boards. To this end, within the 15 days following publication of the new law in the Official Gazette, the government was obliged to adopt a decree establishing the procedure for the setting up, the arrangements for the functioning and the responsibilities of these boards (Art. 5, alin. 4). ${ }^{7}$ They will have to be set up within the 30 days that follow the entry into force of the new law (Art. 5, alin. 1). Unhappily, not every local authority set up these boards within the 30 days that follow the entry into force of the new law, which means that in these cities the restitution process is stopped.

As the new law provides, within the 180 days $^{8}$ that follow their setting up, local land inventory boards will draw up an inventory of the agricultural land and woodland in the public or private ownership of the State or its territorial administrative units which are liable to be the subject of a reconstitution of ownership (Art. 6, alin. 1).

As the effectiveness of the new law depends on the correct functioning of the local land inventory boards without any temptation to conceal municipally owned properties, the selection of the president and the members of the local land inventory boards is a key issue.

It was a general experience during the years 2001-2013 that local authorities did not want to make an inventory of their properties, and they generally did not meet their alternative compensation obligations, making it so that the only means of awarding

7 HG 401/2013 pentru aprobarea Normelor de aplicare a Legii nr. 165/2013 privind masurile pentru finalizarea procesului de restituire, in natura sau prin echivalent, a imobilelor preluate in mod abuziv in perioada regimului comunist in Romania. (Government Decree no. 401/2013 on the Rules of implementation of Law no. 165/2013 on finalisation of the process of physical restitution or alternative compensation in respect of immovable property that wrongly passed into State ownership during the communist regime); HG 89/2014 pentru completarea Normelor de aplicare a Legii nr. $165 / 2013$ privind masurile pentru finalizarea procesului de restituire, in natura sau prin echivalent, a imobilelor preluate abuziv in perioada regimului comunist in Romania, aprobate prin Hotararea Guvernului nr. 401/2013 (Government Decree no. 89/2014 on supplementing the Rules of implementation of Law no. 165/2013 on finalisation of the process of physical restitution or alternative compensation in respect of immovable property that wrongly passed into State ownership during the communist regime).

${ }^{8}$ Now proposed to be prolonged until the $270^{\text {th }}$ day after the entry in force of a draft Act designed to enact OUG 115/2013, but not signed and returned to Parliament by the President of Romania. 
compensation is for the State to give shares in the Property Fund. There was little incentive for local authorities to catalog the goods in their possession if it means they must give them away. Local authorities (mayors) thus transferred the burden onto the shoulders of the state, while local authorities were left without any responsibility.

The original text of the law no. 165/2013 (art. 5 alin. 2) provided that the local land inventory boards will be headed by a person delegated by the prefect, an independent institution from the local authorities, but this provision was soon changed by Law no. $368 / 2013$ under political pressure, and thus, the mayors (primar), who were the principally responsible persons for the failure of the restitution in kind process, will be again the presidents of the local land inventory boards. ${ }^{9}$ The mayors will obstacle the cataloging of the goods in their possession with every means, because they know that they have to give them away.

The task should be contracted out to an independent institution (e.g. the prefect) or an independent company given access to all necessary databases and archives. It is very strange that the ECHR did not criticized this key-issue of the restitution process. There is no incentive for local authorities to catalog the goods in their possession if it means they must give them away, and sanctions are insufficient.

It is true that the decision can be challenged in the courts, but from the outside it's quite hard to demonstrate that there are buildings that can be given as compensation.

\section{d) Administrative delays without sanctions}

Although Law 10/2001 required administrative authorities to resolve claims filed with them within 60 days, this rarely happened in practice. Claimants then went to court to demand an administrative decision.

Statutory time limits for each administrative step are critical to unblocking claimants' access to a court, one of the fundamental requirements of Atanasiu. The government's intention to propose them for local authorities is highly encouraging, but should be required for all administrative phases (Popovici 2011: 28).

The Department for the Execution of Judgments of the European Court of Human Rights noted that some of the time limits set by the draft law for the processing of cases by local authorities and the National Board seem at first sight to be lengthy, but it held that the Romanian authorities are in the best position to assess the realistic nature of these time limits.

The ECHR did not criticized the length of process or the non-compliance with the statutory time limits, moreover, it seems to be ignoring the Government Urgency Ordonance nr. 115/2013 which prolonged the statutory time limits in a significant way. ${ }^{10}$ Moreover, a

9 Legea nr. 368/2013 pentru modificarea şi completarea Legii nr. 165/2013 privind măsurile pentru finalizarea procesului de restituire, în natură sau prin echivalent, a imobilelor preluate în mod abuziv în perioada regimului comunist în România (Law no. 368/2013 on supplementing Law no. $165 / 2013$ on finalisation of the process of physical restitution or alternative compensation in respect of immovable property that wrongly passed into State ownership during the communist regime).

10 O.U.G. nr. 115/2013 pentru instituirea unui nou termen în care să se finalizeze situaţia prevăzută la art. 6 alin. (1) din Legea nr. 165/2013 privind măsurile pentru finalizarea procesului de restituire, în natură sau prin echivalent, a imobilelor preluate în mod abuziv în perioada regimului comunist în România, precum şi pentru prorogarea unor termene (Emergency Government Ordinance no. $115 / 2013$ on the new statutory time limits of Law no. 165/2013 on finalisation of the process of physical restitution or alternative compensation in respect of immovable property that wrongly passed into State ownership during the communist regime). 
further prolongation was voted by the Romanian Parliament in 2014, but the President of Romania refused to sign the bill, and he sent it back to Parliament.

Time limits must be correlated with sufficient capacity at the ANRP and at local authorities with large numbers of unresolved cases, such as those in the Bucharest City Hall, which are also responsible for the blockage at the national level. The capacity to process claims within a reasonable and predictable amount of time will also serve to limit corruption.

As the Department for the Execution of Judgments of the European Court of Human Rights pointed out, the introduction of binding time limits and of sanctions for failure to comply with these is to be welcomed. However, it has to be pointed out that these sanctions represent an indirect means of ensuring that the statutory time limits are complied with, and are not therefore such as directly to remedy the situation, especially if delays are not the result of culpable/negligent conduct by officials, but have other causes, such as possible deficiencies of the law or a lack of (human or other) resources to apply it. ${ }^{11}$

Consequently, in order to ensure that the time limits are not exceeded, the authorities could envisage an automatic mechanism - in the event that a statutory time limit is exceeded - whereby cases are transferred from one administrative stage to the next, until the point at which the compensation decision is issued. Such a mechanism would also avoid intervention of judicial control in the middle of the administrative procedure, but the Romanian Parliament did not adopt this suggestion.

An independent audit should be conducted to assess the institutional, staffing, and financial bottlenecks that keep the ANRP and local authorities (notably those in Bucharest) from processing claims within proposed time limits.

\section{e) Non-application of administrative sanctions and salary penalties}

The previous approach of applying modest fines to institutions has been ineffective. This practice of modest fines has not changed with the new law, because not all cases of tergiversation are sanctioned, and if they are sanctioned, sanctions are ineffective and modest. E.g. there is a sanction if local board do not set up an inventory, but there is no sanction if inventory board is not set up. In fact, there are many local authorities that have not complied with this obligation. Similarly, there is no sanction, if inventory is unprecise, incomplete or unusable.

Instead of modest fines on institutions, salary penalties should be levied not only on individual employees of local and central restitution authorities, but also on the heading persons, presidents of these commissions, boards and administrative authorities, especially the mayors. Salary penalties should be applied in a fast and simple way. These sanctions should be combined with bonuses when targets are substantially exceeded.

\section{f) Problems with the land registry}

Another very important problem of administrative nature is inherent to the land registry system. Throughout time, in Romania, land registration was effected in various ways, the main two systems being that of the transcriptions-inscriptions register (old French model) and the one based on the land books (Austrian model in Transylvania). The superiority of the land book system was unanimously admitted and as a proof the Law of Cadastre and

11 Strain and Others, op.cit. $\S 83-84$. 
Land Registration no. 7/1996 was elaborated, based on which the land registration system based on land books is extended at country level, but there are large areas with no cadastral information. An inventory of real property owned by the State cannot be done if the land registry system does not work. The European Union should finance the introduction of land registration system with non-reimbursable funds, because Romania has not enough financial sources (Scrieciu 2000: 45; Ferenţiu 2010: 134-138, Cardei 2012: 145-154).

\section{g) Non-execution of court decisions}

If tergiversation of administrative authorities is sanctioned by applying modest fines on institutions, or pecuniary compensations are awarded, these court decisions remain often unexecuted because of the OG 22/2002, although in the case of Sandor vs. Romania ${ }^{12}$ the ECHR deemed it to be contrary to the right under Article 6 of the Convention.

\section{PAYMENT OF COMPENSATION IN CASH}

Applicants will be able to opt for the award of pecuniary compensation within the three years that follow receipt of the compensation decision, but not before 1 January 2017. To this end, he or she will be able to make a request, each year, to the ANRP for the issue of a payment certificate for a maximum of $14 \%$ of the number of points awarded by the compensation decision and not used at the auctions. The final instalment will be $16 \%$. The arrangements for cashing in points will be regulated by the implementing rules for the new law (Art. 31).

As we have seen, the period over which payments are to be spread out is seven years, the last instalment would be paid to them in 16 years after the reference date for the calculation of compensation (2013, the year of adoption of the draft law), 32 years after the fall of the Romanian communist regime.

The Romanian authorities said that index-linking of the amount of compensation was not necessary, given the inflation targets set by the government for the years to come. They also stated that the introduction of index-linking could jeopardise the fundamental objective of giving precedence to compensation in equivalent form (land) and to transactions based on the points awarded in compensation, which the authorities intended to encourage. ${ }^{13}$

Account being taken of the length of time which may elapse between the reference date for calculation of the amount of pecuniary compensation (the date on which the new law comes into force) and the date on which the points awarded are used in full, these arguments nevertheless do not seem to provide convincing justification for the absence from the law of provisions introducing an index-linking arrangement to take account of inflation.

However, the ECHR did not hold this period to be unreasonably long, taken into consideration the great number of the restitution claims and the margin of appreciation enjoyed by the Romanian State. In the Case of Preda and others vs. Romania, the ECHR failed to mention non-indexing of the amount of compensation, either.

Yet, the Constitutional Court of Romania do not seem to share the views of a Court so far from Romania and the real situation. ${ }^{14}$ The decision nr. 528 din 12 decembrie 2013 held

12 CEDH, Requête no. 67289/01, 24 mars 2005.

13 Strain and Others, op.cit. 18.

14 Decizie Curtii Constitutionale nr. 528 din 12 decembrie 2013 referitoare la excepţia de 
that the Ordonance of Urgency of the Romanian Government nr. 10/2013 ordering the payment of the pecuniary compensation in instalments for 10 years to persons who are entitled to it, on the ground of the Romanian-Bulgarian Treaty of Craiova, signed on 7 September $1940,{ }^{15}$ and the Paris Peace Treaties signed on 10 February 1947 and other legal sources, is unconstitutional, because a period of 10 years is to be considered too long after a payment delay of 74 years and a previous installment provision for 5 years in 1998, and it is upsetting the fair balance between the general interest and the protection of the individual's right to the peaceful enjoyment of their possessions.

\section{THE INVENTORY OF REAL PROPERTY OWNED BY THE STATE}

Where the restitution of original properties is not possible, Law 10/2001 calls for restitution with other goods in state possession. It was a general experience that local authorities generally did not meet their alternative compensation obligations, making it so that the only means of awarding compensation was for the state to give shares in the Property Fund. The burden was thus transferred onto the shoulders of the state, while local authorities were left without any responsibility. Some local authorities could not or did not want to make an inventory of their properties; some knew what they own, but from the outside it's quite hard to demonstrate that there are buildings that can be given as compensation. The local authorities have no incentive to finish property inventories if it means they will have to give away their possessions (Popovici 2011: 16).

In addition, previously, some courts have held that these measures are obligatory when possible, while others hold that only local authorities can have the discretion to determine

neconstituţionalitate a prevederilor Ordonanţei de urgenţă a Guvernului nr. 10/2013 pentru plata eşalonată a despăgubirilor stabilite potrivit dispoziţiilor Legii nr. 9/1998 privind acordarea de compensaţii cetăţenilor români pentru bunurile trecute în proprietatea statului bulgar în urma aplicării Tratatului dintre România şi Bulgaria, semnat la Craiova la 7 septembrie 1940, ale Legii nr. 290/2003 privind acordarea de despăgubiri sau compensaţii cetăţenilor români pentru bunurile proprietate a acestora, sechestrate, reţinute sau rămase în Basarabia, Bucovina de Nord şi Ţinutul Herţa, ca urmare a stării de război şi a aplicării Tratatului de Pace între România şi Puterile Aliate şi Asociate, semnat la Paris la 10 februarie 1947, precum şi ale Legii nr. 393/2006 privind acordarea de compensaţii cetăţenilor români pentru bunurile trecute în proprietatea fostului Regat al Sârbilor, Croaţilor şi Slovenilor, în urma aplicării Protocolului privitor la câteva insule de pe Dunăre şi la un schimb de comune între România şi Iugoslavia, încheiat la Belgrad la 24 noiembrie 1923, şi a Convenţiei dintre România şi Regatul Sârbilor, Croaţilor şi Slovenilor, relativă la regimul proprietăţilor situate în zona de frontieră, semnată la Belgrad la 5 iulie 1924, precum şi pentru modificarea şi completarea Legii nr. 9/1998, Legii nr. 290/2003 şi Legii nr. 393/2006. (Decision no. 528 of 12 December 2013 of the Constitutional Court of Romania, related to the Emergency Government Ordinance no. 10/2013, on the installments of compensation on the ground of Law no. 9/1998 on compensation to Romanian citizens of Bulgarian state-owned assets in the execution of the treaty between Romania and Bulgaria, Craiova, signed on 7 September 1940, and the Paris Peace Treaties signed on 10 February 1947, on Law no. 393/2006 on compensation to Romanian citizens of Bulgarian state-owned assets in the execution of the Treaty between Romania and Yugoslavia, signed on 24 November 1923, and the Treaty between Romania and the Kingdom of Serbs, Croats and Slovenes, signed in Belgrad, on 5 July 1925).

${ }^{15}$ Under the Romanian-Bulgarian Treaty of Craiova, signed on 7 September 1940, Romania ceded the so-called Quadrilateral to Bulgaria. 
whether a property is indispensable to the public good, and thus not awardable. In the end, the first opinion prevailed. ${ }^{16}$

Law 10/2001 calls for compensation by local authorities with "other goods or services", meaning private property held by the state (as opposed to property in the public domain). This happens very little in practice not because there are no buildings to give, but often because state property inventories are incomplete, despite the fact that inventories were required to be finished by the year 2000 under Law 17/1998. The problem is especially acute in Bucharest.

The new Law no. 165/2013 instituted a new system of compensation, but it does not delete the main problem, the conflict of interests.

According to the new law, the authorities will first set up the inventory of agricultural land and woodland owned by the State or public authorities or institutions which could be used in the compensation process, and will centralise the claims for restitution of that kind of property, in order to be able to produce a comparative table of both. This preparatory stage ought have been completed by 1 March $2014 .{ }^{17}$ Within the 180 days $^{18}$ that follow their setting up, local land inventory boards will draw up an inventory of the agricultural land and woodland in the public or private ownership of the State or its territorial administrative units which is liable to be the subject of a reconstitution of ownership (Art. 6, alin. 1).

The inventories will be approved by the ANRP and then forwarded to the county real estate boards (entities currently functioning in accordance with the restitution legislation in force) (Art. 6, alin. 3). The county boards will centralise the inventories produced on local level, within the 30 days that follow their receipt. The result of the centralisation will then be forwarded to the Agentia Domeniilor Statului (ADS) and to the National Agency for Property Restitution (ANRP) (Art. 6, alin. 4). Within the 60 days that follow receipt of the results of the centralisation for each county, the ADS and ANRP will begin the necessary legislative measures to transfer the land concerned from the public to the private ownership of the State, so that it may be allocated to compensation measures (Art. 6, alin. 5). Within the 30 days that follow publication of these legislative measures in the Official Gazette, the public institutions which own the land concerned will have to transfer it to the ADS. Within the 30 days that follow that transfer, the ADS will inform the county boards of the area of land available in each territorial administrative unit (Art. 9, alin. 1 and 2). In accordance with Art. 9, alin. 3, the transfer of available land to local real estate boards (entities currently functioning in accordance with the restitution legislation in force) will be effected following

16 E.g. Supreme Court of Romania (Î.C.C.J), Secţia civilă şi de proprietate intelectuală, decizia nr. 1895 din 19 martie 2010.

17 This statutory time limit was prolonged until 1 September 2014 by the OUG $115 / 2013$, but now proposed to be prolonged until 1st December 2014 by a draft Act designed to enact OUG 115/2013, but not signed and returned to Parliament by the President of Romania.

18 Now proposed to be prolonged until the $270^{\text {th }}$ day after the entry in force of a draft Act designed to enact OUG 115/2013 (PL-x 118/17.03.2014 Proiect de Lege privind aprobarea Ordonanţei de urgenţă a Guvernului nr.115/2013 pentru instituirea unui nou termen în care să se finalizeze situaţia prevăzută la art.6 alin.(1) din Legea nr.165/2013 privind măsurile pentru finalizarea procesului de restituire, în natură sau prin echivalent, a imobilelor preluate în mod abuziv în perioada regimului comunist în România, precum şi pentru prorogarea unor termene), but not signed and returned to Parliament by the President of Romania. 
validation by the county board of the proposals for the granting of title to this land, by 1 January 2015 at the latest.

In order to make possible the "use of points", the law provides for the setting up of a National Fund of agricultural land and other immovable property (the "National Fund"), administered by the ADS. Initially, this fund will comprise the agricultural land which is the private property of the State and is administered by the ADS, which will not be the subject of restitution/allocation (Art. 21, alin. 2). It will subsequently have added to it other immovable property, including the land not used in the restitution/allocation process, which will be returned to the ADS by the local authorities within the 30 days that follow the date of finalisation of the said process (1 January 2016) (Art. 11, alin. 2, and Art. 21, alin. 3 and 5). By 1 July 2014 at the latest, the ADS will publish on its Internet site and forward to the ANRP the list of immovable property included in the National Fund (Art. 21, alin. 4). The value of each immovable property included in the Fund, established on the basis of the notaries' scale, will be published by 1 January 2015 at the latest. The values of the immovable property subsequently added will be published within 30 days (Art. 21, alin. 7). ${ }^{19}$

With effect from 1 January 2016, entitled parties will be able to use the points awarded to acquire immovable property included in the National Fund and put up for sale by auction. Auctions via videoconferencing will be held each week at the headquarters of the ANRP.

It seems that the local inventory boards headed by the mayor of the city, are entitled to decide themselves which plot of land is susceptible of restitution without any external controll or supervision. The mayors of the cities can diminish the surface area of land which could be returned to former owners. In other words, there is a huge conflict of interests, because local authorities have no incentive to set up an exhaustive inventory, as it means they will have to give away their possessions.

In fact, the local inventory boards are invoking old and new pretexts. E.g., on 11 December 2013, the Monitorul de Vrancea published an article where Dumitru Robu, mayor of Gologanu stated that they do not have enough money to pay the specialists in topography, and therefore only one third of the agricultural land was inventoried, but the remaining two third is missing (Dumitru 2013). Lots of other similar articles were published in the local journals.

Some local administrative authorities succeeded in saving money by charging their own employees specialized in topography with no further costs, but other local administrative authorities concluded expensive contracts, wasting public money unduly, and then they invoked the pretext that they do not have enough financial sources for that purpose.

Moreover, the inventory boards have to catalog only agricultural land and woodland owned by the State or public authorities or institutions, but other immovable properties will remain uninventoried.

Although under Law 112/1995 the former tenants were allowed to buy their dwellings if they were nationalized in accordance with the legal norms in force at that time (,,cu titlu"), the tenants were not allowed to purchase the yard and the garden which sometimes are properties of important economic value. ${ }^{20}$ It is a well-known practice that local administrative authorities are selling these assets sometimes at fractions of the market price, although these plots of lands could be offered for compensation. The Law no. 165/2013 ignores the question, and unhappily the ECHR does so, as well. If the ECHR really desires

19 Strain and Others, op.cit. § 29-33, 35, 37.

20 Art. 26 of Law no. 112/1995. 
a well-functioning compensation, the Court should have suggested to forbid all contracts designed to diminish the surface area available for compensation.

Partially State-Owned Enterprises and public corporations are entirely missing from the new law, and therefore they are not obliged to convey their immovable properties to the National Fund of agricultural land and other immovable property, and that raises serious questions about the effectiveness of the inventory process.

Besides local administrative authorities and State-Owned Enterprises, there are other public entities which possess important assets. According to the art. 20. alin. (3) of Law no. $165 / 2013$, these possessions make part of the National Fund of agricultural land and other immovable property only if they are offered and proposed by the possessing State agencies and public entities themselves. In other words, restitution is optional.

This raises a number of questions about the effectiveness of the inventory process. The inventory making should be contracted out to an independent institution. It should be clarified in law that this is obligatory until private goods held by local authorities are exhausted. It is hardly thinkable, or it is thinkable only for the judges of the ECHR that State agencies and public entities will offer their possessions spontaneously, if it means they will have to give away their possessions.

Art. II of Law 368/2013 amended the Law no. 165/2013 providing that applicants can opt for returning of their file to the local administrative authorities in order to obtain compensation in kind with private property held by the State. This modification raises a question whether land properties of important economic value will be offered to applicants with influential acquaintances. This new legal norm (unknown to the ECHR) is suspected to be designed to subtract State assets from the National Fund of agricultural land and other immovable property, or at least it makes it possible.

The law 165/2013 provides that all administrative procedures in progress at the time when the new law comes into force will be suspended pending centralisation of the inventories by the county boards (Art. 7). Although only administrative procedures were suspended by the law, Romanian courts ordered suspension of judicial procedures demanding an administrative decision from the local authorities. Thus, the right to challenge in court any failure of delivering decision within statutory time limit resulted non existent, and this was not criticized by the ECHR at all.

\section{THE ALLEGEDLY ‘OVERLAPPING’ RIGHTS}

Romania passed its first restitution laws in 1991, concerning agricultural land only. While it capped the amount of land that could be returned, it covered restitution not only to original owners or their descendants, but also to a new class of owners who had never held a title to the land. The law was thus not only restorative but also distributive in nature. When Romania successively increased the amount of land to be restituted in 1997 and 2000, having already given land to a new class of owners in 1991, it had less to give back to the original owners. Compensation was introduced as a costly alternative, when none would have been necessary if Romania had stuck with a restorative or a distributive policy, rather than combining the two (Popovici 2011: 12).

Although the 1991 law did not cover the restitution of buildings, over 1990-1995 many courts began recognizing former owner's property rights under the civil code and ordering restitution. In response, legislators decided to clearly regulate the restitution of buildings, in order to limit it. Thus, Law 112/1995 allowed current tenants to buy their properties from the state for below-market prices; restitution to former owners was now explicitly allowed, 
but only if they resided in the property or if it was vacant, otherwise being entitled to limited compensation. Tenants began buying properties from the state, while courts were simultaneously recognizing that former owners had legitimate title to them (Bîrsan 2007: 5-19; Bîrsan 2005: 145; Popovici 2011: 12).

Overlapping property titles were created: some courts began recognizing the primacy of former owners' property titles, while others recognized those of the "tenants." This gave rise to overlapping rights to the same properties. Law 10/2001 added to the ambiguity, allowing former owners to challenge tenants' titles if not obtained in good faith (Kis 2010: 149; Popescu 2003).

Law $1 / 2009$ paid attention to the plight of (now former) tenants who by court decision were ejected from their apartments in favour the once former (now current) owners. Although former tenants bought their apartments under Law 112/1995 at fractions of the market price, those that lost them are now entitled to their full market value today.

This is paid in cash from an extrabudgetary fund, whereas compensation to former owners was paid through shares in the Fondul Proprietatea, now suspended. There is no reason for this unequal treatment. Former owners should also be compensated through ANRP, and their place in line should also be determined by the date on which their claims were received.

The most important statement of the ECHR in the case of Preda and others vs. Romania regards the acknowledgment of title to the property of former owners. The ECHR held that the ruling by the domestic courts that the nationalisation of property (apartment) had been illegal (fara titlu valabil) amounts to an acknowledgment of title to the property with retrospective effect, even if this ruling was issued after the selling of the property (apartment) to the former tenants. ${ }^{21}$

21 Preda et autres c. Roumanie, $\mathrm{n}^{\text {os }} 9584 / 02$, 33514/02, 38052/02, 25821/03, 29652/03, 3736/03, 17750/03 et 28688/04, CEDH 123 (2014), § 146.: "La Cour rappelle avoir conclu, dans maintes affaires soulevant des questions semblables à celles de la présente espèce, à la violation de l'article 1 du Protocole $\mathrm{n}^{\mathrm{o}} 1$ à la Convention (voir, parmi d'autres, Străin et autres c. Roumanie, $\mathrm{n}^{\mathrm{o}}$ 57001/00, §§ 39, 43 et 59, CEDH 2005-VII, et Porteanu c. Roumanie, $\mathrm{n}^{\circ}$ 4596/03, §§ 32-35, 16 février 2006). Elle a notamment jugé que le constat des tribunaux internes quant à l'illégalité de la nationalisation avait pour effet de reconnaître, avec effet rétroactif, l'existence d'un droit de propriété sur le bien en question (voir, parmi d'autres, Brumărescu c. Roumanie [GC], $\mathrm{n}^{0}$ 28342/95, § 70, CEDH 1999-VII, Strain et autres, précité, $\S \S 26$ et 38, Davidescu c. Roumanie, no 2252/02, § 47, 16 novembre 2006, Popescu et Dimeca c. Roumanie, $\mathrm{n}^{\circ}$ 17799/03, $\S 22$ à 24, 9 décembre 2008, et Mărăcineanu c. Roumanie, $\mathrm{n}^{\mathrm{0}} 35591 / 03, \S 17,9$ février 2010). Elle a également conclu, dans le contexte législatif roumain régissant les actions en revendication immobilière et les lois de restitution permettant la vente aux locataires de biens soumis à restitution, que la vente par l'État du bien d'autrui, même lorsqu'elle est antérieure à la confirmation définitive en justice de l'existence de ce bien, s'analysait en une privation d'un bien au sens de la deuxième phrase du premier alinéa de l'article 1 du Protocole n ${ }^{\mathrm{o}} 1 . "$

("The Court observes that it had held in previous cases and similar to that of the applicants that there was a violation of Article 1 of Protocol no. 1 of the Convention (see, Străin et autres c. Roumanie, $\mathrm{n}^{\mathrm{o}}$ 57001/00, $\S 39,43$ et 59, CEDH 2005-VII, and Porteanu c. Roumanie, $\mathrm{n}^{\circ}$ 4596/03, $\S \S 32-35,16$ February 2006). The Court held that ruling by the domestic courts that the nationalisation of property had been illegal amounted to an acknowledgment of title to the property in question, with retrospective effect (see, Brumărescu c. Roumanie [GC], n 28342/95, § 70, CEDH 1999-VII, Strain et autres, précité, $\S 26$ et 38, Davidescu c. Roumanie, $n^{\circ}$ 2252/02, § 47, 16 novembre 2006, Popescu et Dimeca c. Roumanie, $\mathrm{n}^{\mathrm{0}}$ 17799/03, §§ 22 à 24, 9 décembre 2008, et Mărăcineanu c. Roumanie, $\mathrm{n}^{\mathrm{0}} 35591 / 03$, 
Having regard to the domestic court's ruling that the State had illegally taken possession of the building in question and was thus required to return it to the applicants as the lawful owners, the Court held that their being deprived of their property and not being paid any compensation at all over a period of many years was at variance with Article 1 of Protocol No. 1 and concluded that there had been a violation of that Article in respect of $\mathrm{Mr}$ and Mrs Rodan's property.

Law no. 112/1995 only applied to property in respect of which the State had a valid document of title ( $c u$ titlu), and no other domestic provision entitled the State to sell property that fell without a valid title to the property under its ownership, that is to say for which it had no document of title (fără titlu valabil). Moreover, there was not any statutory basis for the sale to a private individual of property that had been confiscated or nationalised without a valid title to the property (färă titlu valabil). ${ }^{22}$

As the article 966 of the Civil Code reads: "An obligation without legal basis or based on an erroneous or unlawful ground cannot produce any useful effect." This means that these contracts were sanctioned with absolute nullity which might have been invoked without a time limit. If a court had acknowledged, with retrospective effect, that the takeover of their property had been unlawful, infringing the communist legislation in force in that time, another court cannot ignore this judicial decision saying that it was made with good faith.

The Romanian Constitutional Court stated several times that the persons whose properties were taken over (nationalized, confiscated) without valid title maintain the quality of owner they had on the date of the takeover. ${ }^{23}$ Therefore, the former owners whose properties were taken over without title have a real right to ownership protected by art. 44 of the Constitution of Romania.

As to the allegedly overlapping rights, the Constitutional Court stated that the right to ownership of the former tenants of lawfully nationalised dwellings and the right to ownership of the former tenants of unlawfully nationalised dwellings are not equally protected by the Romanian Constitution, ${ }^{24}$ because the former tenants who bought their

17, 9 février 2010). It also found, that under the Romanian legislative framework governing actions for recovery of possession and under Romanian legal practice allowing the sale of the property subject to restitution, the sale by the state of property of others, even when prior to the final acknowledgement in court of the existence of the property right, amounted to a deprivation of property within the meaning of the second sentence of the first paragraph of Article 1 of Protocol No. 1.")

22 Case of Străin and others v. Romania (Application no. 57001/00), § 47b.

23 Curtea Constituţională, Decizia Nr. 482 din 11 decembrie 2003 referitoare la excepţia de neconstituţionalitate a dispoziţiilor art. 2 alin. (2) din Legea nr. 10/2001 privind regimul juridic al unor imobile preluate în mod abuziv în perioada 6 martie 1945 - 22 decembrie 1989 (Decision no. 482/2003 of the Constitutional Court, on the applications regarding art 2. alin. (2) of Law no. 10/2001 of 14 February 2001 on the rules governing immovable property wrongfully seized by the State between 6 March 1945 and 22 December 1989).

24 Decizia Curtii Constitutionale Nr. 292 din 23 mai 2013 referitoare la excepţia de neconstituţionalitate a prevederilor art. $50^{1}$ alin. (1) din Legea nr. 10/2001 privind regimul juridic al unor imobile preluate în mod abuziv în perioada 6 martie 1945-22 decembrie 1989, Publicată în Monitorul Oficial nr. 450 din 23.07.2013.: ,,art. 16 din Constituţie, .... nu ocroteşte în mod egal dreptul de proprietate dobândit de foştii proprietari cu respectarea cerinţelor Legii nr. 112/1995 şi dreptul de proprietate dobândit prin nerespectarea cerinţelor legii sau chiar prin fraudarea ei, deoarece principiul egalităţii impune aplicarea aceluiaşi tratament juridic unor persoane aflate în aceeaşi situaţie juridică. Or, este evident că persoanele menţionate se află în situaţii juridice diferite.” (Decision no. 292/2013 
apartments infringing the provisions of the Law 112/1995 cannot invoke their own fault, as they had known or they ought to know the provisions of the Law 112/1995 in force at the time of the purchase, and no one alleging his own turpitude is to be heard (nemo turpitudinem suam allegans auditur). The Constitutional Court has also stated that a man who founds his cause of action upon an immoral or an illegal act has no right to be assisted, and no person may base a legal claim upon an illegal act. ${ }^{25}$

Although the ECHR stressed the fact that the Convention leaves to the Contracting States a wide margin of appreciation, it stressed also that this margin is given both to the domestic legislator and to the judicial bodies that are called upon to interpret and apply the laws in force, especially the Constitution. This means that if the ECHR finds a breach, this imposes on the respondent State a legal obligation under the Convention to put an end to the breach and make reparation for its consequences, but this cannot be done infringing the Constitution of each contracting state, as it is interpreted by the national Constitutional Court.

Thus, the problem of conflicting rights can be only solved by preferring the right to ownership of the former owners. This can be made by amending the Law no. 10/2001, as follows: „The persons whose dwellings were nationalized without valid legal title, are entitled to lodge an action for anullment of the alienation without time limit notwithstanding art. 45 alin. (5) of Law no. 10/2001, if the title of the State had been declared void by the courts." 26

An infringement of the Romanian Constitution and the conflict with internal law is to be avoided, because it undermines legal certainty, and it may give raise to new applications to the ECHR.

In the past, the ECHR committed such errors suggesting solutions which were later declared unconstitutional by the Constitutional Court of Romania. E.g., the ECHR emphasized the need to cover all the situations found to be in violation of the Convention in the Strain group of cases, and it suggested that the provisions of the draft law should also apply to those persons who have lodged an application with the European Court of Human Rights, and applications pending before the Romanian Courts. Several decisions of the Constitutional Court held that these provisions are not constitutional because of the retroactivity. ${ }^{27}$ It seems that the main goal of the ECHR is to reduce its caseload, rather than enhancing protection level of human rights.

of the Constitutional Court, on the applications regarding art. $50^{1}$ alin. (1) of Law no. 10/2001 of 14 February 2001 on the rules governing immovable property wrongfully seized by the State between 6 March 1945 and 22 December 1989, published in the Official Gazette of Romania no. 450 of 23 July 2013).

25 Curtea Constituţională, Decizia Nr. 425/2008.

26 Persoanele ale caror imobile au fost preluate de Stat făă titlu valabil, pot introduce actiunea pentru constatarea nulitaţii actelor juridice de instrainare oricând prin derogare de la art. 45 alin. (5) din legea 10/2001, dacă prin hotarârea judecatorească irevocabilă s-a constatat că imobilul a fost preluat fârâ titlu valabil.

27 Decizia Curtii Constitutionale nr. 88/2014 referitoare la excepţia de neconstituţionalitate a prevederilor art. 4 teza a doua raportate la cele ale art. 33 din Legea nr. 165/2013 privind măsurile pentru finalizarea procesului de restituire, în natură sau prin echivalent, a imobilelor preluate în mod abuziv în perioada regimului comunist în România: Dispoziţiile art. 4 teza a doua sunt constituţionale în măsura în care termenele prevăzute la art. 33 din aceeaşi lege nu se aplică şi cauzelor în materia restituirii imobilelor preluate abuziv, aflate pe rolul instanţelor la data intrării în vigoare a legii. (Decision no. 88/2014 of the Constitutional Court, on the applications regarding art. 4 and art. 33 of 


\section{FURTHER GRIEVANCES OF THE HOLOCAUST AND COMMUNIST REGIME VICTIMS ON THE ECHR PRACTICE ON PROPERTY RESTITUTION IN ROMANIA}

As we have seen, the ECHR rejected applications of holocaust and communist regime victims arguing that Law no. 165/2013 had been enacted only recently, and falsely stating that no judicial or administrative practice had yet emerged as regards its application, and thus the Court could see no reason to conclude at this stage that the new remedy was ineffective, the the new legal framework offered litigants an opportunity to obtain redress for their grievances at national level; it was for them to avail themselves of that opportunity.

However, we have seen previously that the ECHR assessment on the new restitution legislation is rather superficial and not convincing. Legal writers such as Rugină Florin emphasized: "It is the European Court of Human Rights that made suggestions for such provisions that go against the basic law of the country. In my opinion this shows how limited the knowledge of the Strasbourg Court is with respect to the national legislation and practice of the country." (Rugină 2012: 58) The ECHR suggested solutions that are unconstitutional, ineffective and full of contradictions, and the Court ignores important legal norms enacted after the Law no. 165/2013. It seems that the ECHR was only concerned with the excessive caseload rather than the effective protection of holocaust and communist regime victims. However, this paranoid concern about excessive caseload may give raise to new applications to the ECHR.

Furthermore, Holocaust and communist regime victims and non-governmental organizations raised doubts not only about the effectiveness of the pilote procedure, but also on the independence of the Court. Judges, their spouses and their minor children are entitled to the privileges, immunities, exemptions and facilities accorded to diplomatic envoys in accordance with international law, as is also reflected in Articles 29 to 36 of the Vienna

Law no. 165/2013 on finalisation of the process of physical restitution or alternative compensation in respect of immovable property that wrongly passed into State ownership during the communist regime);

Decizia Curtii Constitutionale Nr. 210 din 8 aprilie 2014 referitoare la exceptia de neconstitutionalitate a dispozitiilor art.4 teza a doua raportate la cele ale art.1 alin.(2) din Legea nr.165/2013 privind măsurile pentru finalizarea procesului de restituire, în natură sau prin echivalent, a imobilelor preluate în mod abuziv în perioada regimului comunist în România, în redactarea anterioară modificării acestor prevederi prin Legea nr. 368/2013 pentru modificarea si completarea Legii nr. 165/2013.; (Decision no. 210/2014 of the Constitutional Court, on the applications regarding art. 4 and art.1 alin.(2) of Law no. 165/2013 on finalisation of the process of physical restitution or alternative compensation in respect of immovable property that wrongly passed into State ownership during the communist regime);

Decizia Curtii Constitutionale a Romaniei nr. 269/2014 referitoare la exceptia de neconstitutionalitate a prevederilor art. 4 teza a doua raportate la art. 7 alin. (1), art. 11 alin. (1) si (2), art. 16, art. 17 alin. (1) lit. a), art. 21 alin. (6) si (8), art. 31 alin. (5), art. 34 alin. (1), art. 35 alin. (2) si art. 50 lit. b) teza intai din Legea nr. 165/2013 privind masurile pentru finalizarea procesului de restituire, in natura sau prin echivalent, a imobilelor preluate in mod abuziv in perioada regimului comunist in Romania, (Monitorul Oficial, Partea I, nr. 513 din 9 iulie 2014). (Decision no. 269/2014 of the Constitutional Court, on the applications regarding art. 4 and la art. 7 alin. (1), art. 11 alin. (1) si (2), art. 16, art. 17 alin. (1) lit. a), art. 21 alin. (6) si (8), art. 31 alin. (5), art. 34 alin. (1), art. 35 alin. (2) si art. 50 lit. b) of Law no. 165/2013 on finalisation of the process of physical restitution or alternative compensation in respect of immovable property that wrongly passed into State ownership during the communist regime). 
Convention on Diplomatic Relations. ${ }^{28}$ In the past, Romania was accused to have infringed these norms. ${ }^{29}$ As a consequence of these attacks every judge may consider refusing to take part in delicate cases, as press allegations suggested.

Non-governmental organizations criticized the priority treatment of certain restitution cases while other cases have remained unresolved for years. E.g., the case of Gridan and others vs. Romania was unusually quickly resolved, and an (ex-)politician involved in this case obtained 130,900 euros, but only the initials of the parties involved were made public. ${ }^{30}$

"The Court does not provide a reasoning for which it has chosen a case to be considered under the pilot-judgment procedure. While it seems that this has to do with practical and political, as well as legal factors, more clarity would be needed in this extent. This is particularly important for the applicants as, for example, in Atanasiu and others the applicants were awarded compensation for the damages suffered, while the applicants in other 266 cases might have felt discriminated for not knowing at least the reasons why their case was not selected to be treated under the pilot-judgment procedure." - as Rugină Florin noted (Rugină 2012: 60-61).

Another important question raised by non-governmental organizations regards the secondments of Romanian national lawyers to the Registry. Their number has increased significantly since the Interlaken Declaration of 19 February 2010. In that Declaration, the High Level Conference called on the States Parties to the Convention to consider the possibility of seconding national judges and other high-level independent lawyers to the Court's Registry as part of the efforts to increase national authorities' awareness of Convention standards and to implement the Convention at the national level. It should be noted, in this connection, that the Court has had to address concerns regarding the work of a certain category of seconded lawyers ${ }^{31}$ not only from Romania, but also from Russia. Questions have been raised relating to their access to confidential or restricted information and their de facto decision-making power.

On the ground of Protocol 14 single judges can now declare cases inadmissible, and this is a huge and excessive power. The single judges are never from the country against which the relevant applications are lodged, therefore they do not know the language of that State. Large files of application are rarely entirely translated in French or English, therefore single judges are softly constrained to accept the proposed solutions. The Romanian Ministery of Justice has publicly and proudly praised the seconded Romanian national lawyers because the number of applications declared admissible has diminished by $29 \%$ due to their activity. ${ }^{32}$

28 Reinforcement of the independence of the European Court of Human Rights, 05 June 2014, Doc. 13524, Report by the Committee on Legal Affairs and Human Rights, Parliamentary Assembly, Council of Europe, Rapporteur: Mr Boriss Cilevičs, Latvia, § 17.

${ }^{29}$ ECHR Press release, 10 October 2011: "in carrying out a search in the home of the Romanian judge as part of an inquiry concerning allegations about his wife the rules on immunity may not have been respected."

$30 \mathrm{http}$ //www.luju.ro/dezvaluiri/anchete/justitiara-pdl-fericita-de-cedo-monica-macovei-acastigat-la-strasbourg-procesul-intentat-statului-pentru-ca-justitia-a-luat-casa-parintilor-ei-familiamacovei-a-primit-130-900-euro-daune

31 See, for example, the Open Letter to the President of the European Court of Human Rights of 1 December 2011 from Russian human rights activists, and the reply of the Registrar of the Court.

32 Consiliul Superior al Magistraturii, Hotarârea nr. 152 din 14 marţie 2013.: „Numărul cererilor romaneşti aflate pe rolul Curţii a scăzut cu $29 \%$, acest rezultat datorându-se, în mare parte aportului celor 3 jurişti naţionali detaşaţi." 
Certain NGOs have indicated to the Rapporteur of the Committee on Legal Affairs and Human Rights, Mr Boriss Cilevičs that this situation is still in need of clarification. ${ }^{33}$ In any case, it seems clear that a number of essential issues relevant to the secondment are still on the table, and this practice should be avoided, because it is not fully in line with the strict requirements set by the Convention.

\section{CONCLUSIONS}

In summarizing our investigations, we can see that the ECHR has defended with success the applicant's interest in benefiting from a higher level of protection of human rights in Romania during the last decades. ${ }^{34}$ However, as it was also stated by Ronald Lauder, quoted before, this success is very modest, so far. There are a lot of things to do not only for Romania improving the legislation and the administrative practice, but also for the ECHR enhancing the effectiveness of the solutions suggested by the Court. In fact, the judgements of the ECHR regarding Romania often betray an excessive concern about reducing caseload and a pervasive ignorance of the practice of the administrative authorities and inattention of the jurisprudence of the Constitutional Court. ${ }^{35}$

\section{REFERENCES}

Bazyler, J.-Alford, R. (2006): Holocaust Restitution: Perspectives on the Litigation and Its Legac. New York, New York University Press, 304-310.

Berechet, M. (2013): Caracterul concret şi efectiv al dreptului de proprietate asupra imobilelor preluate abuziv în perioada regimului comunist în România conferit prin măsurile de restituire instituite de Legea nr. 165/2013 [The practical and effective nature of the ownership right over real properties taken over in an abusive way during the communist regime in Romania, in virtue of the measures of restitution established by Law nr 165/2013], Revista Română de Jurisprudenţă nr. 3: 20-34; nr. 4: 171-189.

Bîrsan, C. (2005): Convenţia europeană a drepturilor omului. Comentariu pe articole. [The European Convention on Human Rights. A commentary by articles.] Prof. dr. Corneliu Bîrsan. Bucureşti: All Beck, 2005-. 2 vol. (Comentarii Beck / Ed. C.H. Beck).

Bîrsan, C. (2006): Convenţia europeană a drepturilor omului. [The European Convention on Human Rights.] Corneliu Bîrsan, Marius Eftimie. Bucureşti: Editura Hamangiu, 172.

Bîrsan, C. (2007): La protection du droit de propriete: developpements récents de la jurisprudence de la Cour européenne des droits de l'homme, în Liber Amicorum Luzius Wildhaber, Human RightsStrasbourg Views, Droits de l'homme-Regards de Strasbourg, Kehl, N. P. Engel Publisher, 5-19.

Cardei, M. (2012): Aspects regarding the necessity of a unique digital cadastral plan for a territorial administrative unit, Geographia Napocensis 6 (2): 145-154.

CEDH, Străin et autres c. Roumanie, Recueil 2005-VII.

CEDH, Brumărescu c. Roumanie [GC], no 28342/95, § 70, CEDH 1999VII.

CEDH, Davidescu c. Roumanie, no 2252/02, § 47, 16 novembre 2006.

CEDH, Kopecky c. Slovaquie, Recueil 2004-IX.

CEDH, Mărăcineanu c. Roumanie, no 35591/03, § 17, 9 février 2010.

CEDH, Păduraru c. Roumanie, Recueil 2005-XII.

CEDH, Popescu et Dimeca c. Roumanie, no 17799/03, §§ 22 à 24, 9 décembre 2008.

CEDH, Pressos Compania Naviera S.A. et autres c. Belgique, Série A, Recueil 1995-VII.

33 Reinforcement of the independence, op.cit. § 39-40.

34 Preda et autres c. Roumanie, $\mathrm{n}^{\text {os }}$ 9584/02, 33514/02, 38052/02, 25821/03, 29652/03, 3736/03, 17750/03 et 28688/04, CEDH 123 (2014)

35 This paper was supported by the János Bolyai Scholarship. 
Dumitru, C. (2013): O treime din terenuri au fost inventariate pentru retrocedare, Monitorul de Vrancea (11 December 2013), available at <http://www.monitorulvn.ro/articole/o-treime-dinterenuri-au-fost-inventariate-pentru-retrocedare_2_155760.html $>$.

Ferenţiu, G. C. (2007): Retrocedarea imobilelor preluate abuziv, Bucureşti, Editura Hamangiu.

Ferenţiu, G. C. (2010): În legătură cu circulaţia juridică a terenurilor dobândite prin constituirea dreptului de proprietate în temeiul Legii nr. 18/1991, Dreptul 8: 134-138.

Kis, A. (2010): România la Curtea Europeană a Drepturilor Omului (2005-2008). [Romania at the European Court of Human Rights.] Kis Attila. Bucureşti: Wolters Kluwer.

Popescu, C. (2003): Hotărârile Curţii Europene a Drepturilor Omului pronunţate în cauzele împotriva României (1998-2002). [Decisions of the European Court of Human Rights adopted in cases against Romania, 1998-2002.] Bucureşti: All.

Popovici, A. (2011): Romania's Property Restitution Reform. Policy Memo nr. 23, October 2011.

Quesada, (2013): L'arret pilote Maria Atanasiu et autres contre Roumanie. In: In honorem Corneliu Bîrsan, coord. de A. Almăşan, Bucureşti, Ed. Hamangiu, 694-705.

Rugină F. (2012): The pilot judgment procedure of the European Court of Human Rights: A case study on its efficiency. Unprinted thesis.

Scrieciu, F. (2000): Drept agrar si Drept funciar, Bucuresti, Editura Lumina, 45.

Strain and Others against Romania and Maria Atanasiu and Others against Romania (and 266 similar cases) group. General measures for the execution of the judgments of the European Court. Memorandum prepared by the Department for the Execution of Judgments of the European Court of Human Rights, in close co-operation with the Registry of the European Court, H/Exec(2013)1 10 April 2013.

Stoian, M. A. (2009): The property right's juridical means of defence and its implications in CEDO's jurisprudence, in Analele Universitatii Titu Maiorescu Seria Drept, 134-155.

Reinforcement of the independence of the European Court of Human Rights, 05 June 2014, Doc. 13524, Report by the Committee on Legal Affairs and Human Rights, Parliamentary Assembly, Council of Europe, Rapporteur: Mr Boriss Cilevičs, Latvia. 